\title{
A high-resolution system for metabolic imaging of cancer
}

\author{
Eduardo H Moriyama ${ }^{1 *}$, Eric Leung ${ }^{2}$, Naz Chaudary ${ }^{3}$, Tuula Kalliomaki ${ }^{3}$, Richard P Hill ${ }^{3}$, Brian C Wilson?', \\ Michael Milosevic ${ }^{2}$
}

From São Paulo Advanced School of Comparative Oncology

Águas de São Pedro, Brazil. 30 September - 6 October 2012

\begin{abstract}
Alterations in metabolic signaling pathways allow tumors to achieve balance between oxygen supply and consumption via activation of several genes involved in adaptation to low oxygen conditions (hypoxia). Hypoxia stimulates glucose uptake, glycolysis and changes in mitochondrial respiration in tumors as a direct result of increased HIF-1 transcriptional activity. HIF-1 $\alpha$ stabilization induces the expression of genes involved in cell survival, proliferation, angiogenesis and glucose transport (GLUTs) and the stimulation of genes involved in glycolytic energy production. Elevated anaerobic metabolism results in increased production of lactate as an alternate cellular energy source. Recent studies suggested that increased levels of lactate in tumors are associated with tumor progression, development of metastases, radioresistance and decrease of patient survival. Therefore, the ability to monitor products of altered metabolism in tumors would provide valuable information to improve cancer treatment.
\end{abstract}

We have developed a novel high-resolution imaging system to assess the distribution of metabolites in tumors such as lactate and ATP. Initial tests demonstrate the capacity of this technique in providing quantitative measurements of metabolites with high spatial resolution. This technology offers several important advantages over other techniques including ease of translation to the clinic, microscopic spatial localization and quantitation of metabolite concentration. Another advantage on the use of this technique is the possibility of spatial co-registration of metabolites with other tumors biomarkers. The main focus of this approach is the development of novel technologies for imaging tumor metabolism. This will lead to a better understanding of the role of tumor metabolism in

\footnotetext{
* Correspondence: eduardo.moriyama@uhnres.utoronto.ca

'Division of Biophysics and Bioimaging, Princess Margaret Hospital, Ontario Cancer Institute, Toronto, ON, Canada

Full list of author information is available at the end of the article
}

treatment outcome, leading to more rationale therapeutic protocols.

\section{Financial support}

The Terry Fox Foundation, Canada.

\section{Author details}

'Division of Biophysics and Bioimaging, Princess Margaret Hospital, Ontario Cancer Institute, Toronto, ON, Canada. ${ }^{2}$ Radiation Medicine Program, Princess Margaret Hospital, Ontario Cancer Institute, Toronto, ON, Canada. ${ }^{3}$ The Campbell Family Institute for Cancer Research, Ontario Cancer Institute, Toronto, ON, Canada.

Published: 4 April 2013

doi:10.1186/1753-6561-7-S2-03

Cite this article as: Moriyama et al: A high-resolution system for metabolic imaging of cancer. BMC Proceedings 2013 7(Suppl 2):O3.

Submit your next manuscript to BioMed Central and take full advantage of:

- Convenient online submission

- Thorough peer review

- No space constraints or color figure charges

- Immediate publication on acceptance

- Inclusion in PubMed, CAS, Scopus and Google Scholar

- Research which is freely available for redistribution

Submit your manuscript at www.biomedcentral.com/submit
() Biomed Central

\section{Biomed Central}

